Luiz Roberto Ramos'

Deborah Carvalho Malta"

Grace Angélica de Oliveira Gomes"II

Mário M Bracco ${ }^{\mathrm{IV}}$

Alex Antonio Florindo ${ }^{v}$

Gregore Iven Mielke ${ }^{\mathrm{VI}}$

Diana C Parra ${ }^{\text {VII }}$

Felipe Lobelo ${ }^{\text {vIII }}$

Eduardo J Simoes ${ }^{\mathrm{IX}}$

Pedro Curi Hallal ${ }^{x}$

Departamento de Medicina Preventiva. Universidade Federal de São Paulo. São Paulo, SP, Brasil

Secretaria de Vigilância Epidemiológica. Ministério da Saúde. Brasília, DF, Brasil

III Núcleo de Atividade Física, Esporte e Saúde. Universidade Estadual de São Paulo. Rio Claro, SP, Brasil

Hospital Israelita Albert Einstein. São Paulo, SP, Brasil

Escola de Artes, Ciências e Humanidades. Universidade de São Paulo. São Paulo, SP Brasil

vı Programa de Pós-Graduação em Epidemiologia. Universidade Federal de Pelotas. Pelotas, RS, Brasil

VII Prevention Research Center in St. Louis. George Warren Brown School of Social Work. Washington University in St. Louis. St. Louis, MO, USA

VIII Division of Diabetes Translation. National Center for Chronic Disease Prevention and Health Promotion. Centers For Disease Control and Prevention. Atlanta, GA, USA

x School of Medicine. Department of Health Management and Informatics. University of Missouri. Columbia, MO, USA

Faculdade de Educação Física. Universidade Federal de Pelotas. Pelotas, RS, Brasil

Correspondência | Correspondence: Luiz R. Ramos

Setor de Estudos do Envelhecimento

Rua Dr. Bacelar, 384

04026-000 São Paulo, SP, Brasil

E-mail: Irr@uol.com.br

Received: $11 / 18 / 2013$

Approved: $6 / 17 / 2014$

Artigo disponível em português e inglês em: www.scielo.br/rsp

\section{Prevalence of health promotion programs in primary health care units in Brazil}

\author{
Prevalência de programas de \\ promoção da saúde em unidades \\ básicas de saúde no Brasil
}

\begin{abstract}
OBJECTIVE: Assessment of prevalence of health promotion programs in primary health care units within Brazil's health system.

METHODS: We conducted a cross-sectional descriptive study based on telephone interviews with managers of primary care units. Of a total 42,486 primary health care units listed in the Brazilian Unified Health System directory, 1,600 were randomly selected. Care units from all five Brazilian macroregions were selected proportionally to the number of units in each region. We examined whether any of the following five different types of health promotion programs was available: physical activity; smoking cessation; cessation of alcohol and illicit drug use; healthy eating; and healthy environment. Information was collected on the kinds of activities offered and the status of implementation of the Family Health Strategy at the units.
\end{abstract}

RESULTS: Most units (62.0\%) reported having in place three health promotion programs or more and only $3.0 \%$ reported having none. Healthy environment $(77.0 \%)$ and healthy eating $(72.0 \%)$ programs were the most widely available; smoking and alcohol use cessation were reported in $54.0 \%$ and $42.0 \%$ of the units. Physical activity programs were offered in less than $40.0 \%$ of the units and their availability varied greatly nationwide, from $51.0 \%$ in the Southeast to as low as $21.0 \%$ in the North. The Family Health Strategy was implemented in most units $(61.0 \%)$; however, they did not offer more health promotion programs than others did.

CONCLUSIONS: Our study showed that most primary care units have in place health promotion programs. Public policies are needed to strengthen primary care services and improve training of health providers to meet the goals of the agenda for health promotion in Brazil.

DESCRIPTORS: Health Programs and Plans. Health Centers. Health Promotion. Primary Health Care. Health Surveys. 


\section{RESUMO}

OBJETIVO: Estimar a prevalência de programas de promoção da saúde nas unidades básicas de saúde no Brasil.

MÉTODOS: Estudo transversal descritivo realizado por meio de entrevistas telefônicas com coordenadores de unidades básicas de saúde. Do total de 42.486 unidades básicas de saúde cadastradas pelo Ministério da Saúde, 1.600 foram aleatoriamente selecionadas. As unidades foram amostradas nas cinco regiões do País de acordo com a proporção de unidades em cada região. Foi analisada a presença ou não de cinco programas de promoção da saúde: promoção de atividade física, cessação de tabagismo, cessação de uso de álcool e drogas ilícitas, alimentação saudável e ambiente saudável. Foram coletados dados sobre o tipo de ações desenvolvidas nos programas e a presença ou não da Estratégia de Saúde da Família na unidade.

RESULTADOS: A maioria das unidades básicas de saúde $(62,0 \%)$ referiu ter pelo menos três programas de promoção da saúde e apenas $3,0 \%$ não tinha nenhum. A promoção do ambiente saudável e da alimentação saudável foram os programas mais prevalentes ( $77,0 \%$ e $72,0 \%$, respectivamente), enquanto o controle do tabaco e do álcool foram referidos em $54,0 \%$ e $42,0 \%$ das unidades de saúde, respectivamente. A promoção de atividade física foi referida em menos de $40,0 \%$ das unidades e teve grande variação regional, com prevalência de $51,0 \%$ nas unidades do Sudeste e apenas $21,0 \%$ nas do Norte. A maioria das unidades de saúde $(61,0 \%)$ oferecia Estratégia de Saúde da Família, porém não foi verificada maior prevalência de programas de promoção da saúde nessas unidades em relação às outras.

CONCLUSÕES: Este estudo mostrou que programas de promoção da saúde estão presentes na maioria das unidades básicas de saúde. Políticas públicas devem fortalecer a infraestrutura das unidades básicas de saúde e melhorar a capacitação dos trabalhadores de saúde para executar adequadamente a agenda de promoção de saúde do governo brasileiro.

DESCRITORES: Planos e Programas de Saúde. Centros de Saúde. Promoção da Saúde. Atenção Primária à Saúde. Inquéritos Epidemiológicos.

\section{INTRODUCTION}

In the light of population aging and the consequent growing burden of non-communicable chronic diseases (NCDs), health promotion is a key public health strategy for tackling the NCD epidemic worldwide. ${ }^{a}$ Epidemiological data have shown that, in 2008 in Brazil, a third of the general population (almost 60 million people) reported at least one NCD. ${ }^{b}$

With the implementation of the universal health care model in Brazil - the Unified Health System (SUS) -, the Family Health Strategy (FHS) has been established as a crucial entry point to care for users into the health system. In this model, FHS teams work in specific geographic areas and are responsible for implementing actions for health promotion, disease prevention, treatment of common health conditions and rehabilitation. ${ }^{14}$ Currently, most primary health care units (PHCUs) (over $70.0 \%$ ) have FHS teams providing care to around $60.0 \%$ of the Brazilian population. ${ }^{\text {c }}$

${ }^{a}$ World Health Organization. Ageing and Health Programme Division of Health Promotion, Education and Communication. The Hildelberg guidelines for promoting physical activity among older persons: guidelines series for healthy ageing - I. Heidelberg, Germany; 1996 [cited 2013 Dec 6]. Available from: www.who.org

b Ministério da Saúde. Secretaria de Vigilância em Saúde. Departamento de Análise de Situação de Saúde. Saúde Brasil $2008: 20$ anos de Sistema Único de Saúde (SUS) no Brasil. Brasília (DF); 2009. (Série G Estatística e Informação em Saúde).

c Ministério da Saúde. Secretaria de Vigilância em Saúde. Departamento de Análise de Situação de Saúde. Plano de ações estratégicas para o enfrentamento das doenças crônicas não transmissíveis (DCNT) no Brasil 2011-2022. Brasília (DF); 2011. Available from: www.saude.gov.br/bvs 
Health promotion actions have been implemented in primary care in Brazil for less than a decade. The National Health Promotion Policy was introduced in 2006 and its main goals are to promote quality of life and reduce vulnerabilities and risk factors relating to known health determinants. This policy set several high priority actions including promoting healthy eating, physical activity, and tobacco and alcohol cessation, preventing violence, and promoting a sustainable environment. ${ }^{\mathrm{d}}$

Since 2006, the regular Telephone-based Surveillance of Risk and Protective Factors for Chronic Diseases Survey (VIGITEL) has provided vital epidemiological information on main NCD risk factors in the Brazilian population nationwide. Given the high prevalence of physical inactivity reported in VIGITEL surveys, actions for promoting physical activity has become a priority in Brazil for the Ministry of Health. ${ }^{15}$

A systematic review of physical activity interventions in Brazil has shown novel interventions that need assessment of their effectiveness. ${ }^{89}$ A study conducted in the city of Recife, Northeastern Brazil, evaluated the program City Gyms (Academias da Cidade $^{\mathrm{e}}$ ) that offered free open spaces for outdoor physical activity, with infrastructure and guidance of trained staff. This study was part of an international collaborative research project between Brazil and the United States - the Guide for Useful Interventions for Physical Activity in Brazil and Latin America (GUIA project). ${ }^{19, \mathrm{f}}$ It showed that City Gyms are an effective approach for promoting physical activity at the population level. ${ }^{18,21}$ The program was then expanded statewide in Pernambuco, Northeastern Brazil, and further assessed. ${ }^{g}$ Pooled results from these assessments supported the decision-making of the Ministry of Health to implement the nation's health promotion policy, Health Academies (Academias da Saúde ${ }^{\mathrm{h}}$ ) spaces at the primary health care network, with infrastructure, equipment, and staff to encourage and guide people to engage in physical activities. ${ }^{15}$

Although considered a priority, health promotion programs are not yet available in all health care units. Several studies have assessed the effectiveness of health promotion actions in different settings, ${ }^{\mathrm{i}}$ but little is known about how prevalent these programs are among PHCUs within the SUS.

This study aimed to analyze the prevalence of health promotion programs in PHCUs in Brazil.

\section{METHODS}

We conducted a cross-sectional study based on telephone interviews with managers of a randomly selected sample of PHCUs nationwide as part of the GUIA Project. ${ }^{19}$ The detailed methods have been published elsewhere. ${ }^{3}$ In brief, of a total of 42,486 PHCUs listed in the SUS directory, 1,600 were randomly selected to participate in the study. This sampling approach allowed to covering all five Brazilian macroregions and selecting PHCUs proportionally to the number of units in each region. Managers of the selected PHCUs were eligible and invited to participate. Trained interviewers conducted phone interviews that lasted on average 40 minutes. The survey was carried out between January and June 2011.

We estimated the sample size assuming that each type of health promotion program would be available in $50.0 \%$ of the PHCUs, with a 95\% confidence interval and 4 percent points of confidence limit. Thus, it would be necessary a sample of 592 PHCUs. The sample was increased by $10.0 \%$ to cover possible losses and refusals, totaling 642 PHCUs. Given the study's multipurpose characteristic, we sampled 1,600 units so that we could analyze information collected from medical doctors, nurses and health workers from each PHCU.

We examined whether any of the following five different types of health promotion program was available in the PHCU: promotion of physical activity; smoking cessation; alcohol and illicit drug use cessation; healthy eating; and healthy environment. For each program, information was collected on the kind of activities offered. Data were analyzed using SPSS version 13.1, frequencies of health promotion programs were described by category of care unit and macroregion. PHCUs were categorized as follows based on the status of implementation of FHS: FHS only; traditional care strategy with no FHS (TRAD); and mixed

\footnotetext{
d Ministério da Saúde. Secretaria de Vigilância em Saúde. Secretaria de Atenção à Saúde. Política Nacional de Promoção da Saúde. Brasília (DF): 2010. (Série Pactos pela Saúde 2006; 7).

e The Government of Pernambuco in Brasil, have sponsored open spaces in the city of Recife, equipped for physical activity and with a professional available in the beginning and at the end of the day, free of charge for those attending. It became known as the city gyms: Prefeitura da Cidade de Recife. Academia da cidade. Recife (PE); 2008 [cited 2013 Dec 1]. Available from: http://www2.recife.pe.gov.br/ projetos-e-acoes/projetos/academia-da-cidade/

'Project GUIA was a joint venture of American and Brazilian universities, sponsored by the CDC in Atlanta, that conducted several studies in Brazil concerning the promotion of physical activity, which led to the present study: a complete view of the project and its results. Washington (DC); 2005 [cited 2013 Dec 1]. Available from: http://www.projectguia.org/

g Ministério da Saúde. Atividade física no Brasil: uma revisão de evidências em experiências selecionadas. In: Saúde Brasil 2010: uma análise da situação de saúde e de evidências selecionadas de impacto de ações de vigilância em saúde. Brasilia (DF); 2011.

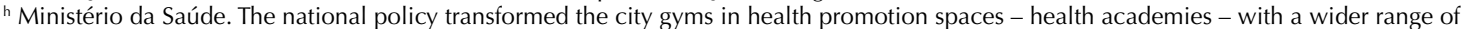
activities. Brasília (DF); 2002. Available from: http://portal.saude.gov.br/portal/saude/profissional/visualizar_texto.cfm?idtxt=37245\&janela=1 ' Health Canada. Health Promotion Effectiveness. Health Promotion - Does it work? Health Policy Res Bull. 2002 [cited 2013 Dec 1];1(3):3-30. Available from: http://www.hc-sc.gc.ca/sr-sr/alt_formats/hpb-dgps/pdf/pubs/hpr-rps/bull/2002-3-promotion/2002-3-promotion-eng.pdf
} 
implementation of both care strategies (MIX). The 27 Brazilian states are divided into five macroregions; North; Northeast; South; Southeast; and Midwest.

The study was approved by the national ethics research committee (Conselho Nacional de Ética em Pesquisa - Protocol 16154, 2010).

\section{RESULTS}

Our sample comprised 1,600 PHCU from all five macroregions, selected roughly proportionally to the population in each macroregion in relation to the total population of Brazil. For instance, $39.0 \%$ of the PHCUs selected were in the Northeast though this macroregion accounts for $28.0 \%$ of the total population. On the other hand, $30.0 \%$ of the PHCUs selected were from the Southeast though it accounts for $42.0 \%$ of the total population. We interviewed 1,251 PHCU's managers, and the overall response rate was $78.0 \%$ ranging from $90.0 \%$ in the South to $58.0 \%$ in the North (Table 1). We have no information on the category of PHCU and background of the manager for cases with missing data.

Most managers (76.9\%) had a nursing background and only $1.9 \%$ were medical doctors. Most PHCUs were categorized as FHS only $(60.8 \%)$, whereas $23.6 \%$ were TRAD, and $15.6 \%$ MIX.

Table 2 shows the prevalence of each type of health promotion program in the primary health care system, by category of PHCU. Physical activity promotion was reported in $39.8 \%$ of PHCU, with no significant differences between the three categories of PHCUs: $39.8 \%$ in FHS only, $37.4 \%$ in TRAD, and $43.3 \%$ in MIX. The most frequently reported activities were supervised walking groups $(81.1 \%)$, stretching and relaxation (77.3\%), and fitness evaluation (67.1\%). ${ }^{4}$

Promotion of tobacco cessation was reported in $54.4 \%$ of PHCUs, but it was significantly more prevalent in TRAD $(60.1 \%)$ when compared to FHS (51.9\%) and MIX (55.7\%). Smoking cessation campaigns were reported in $66.2 \%$ of PHCUs, followed by group counselling (51.6\%), and use of medication for smoking cessation that was reported in only $32.8 \%$ of PHCUs.
Alcohol and illicit drug use prevention was reported in $41.6 \%$ of PHCUs, with no differences between the three categories of PHCUs. Of those PHCUs having an alcohol cessation program, only $43.3 \%$ referred users to specialized care, and more than half $(51.8 \%)$ had support groups.

Healthy eating promotion was reported in most PHCUs $(72.0 \%)$, but this program was significantly less available in MIX PHCUs (64.4\%). The activities reported included training of health professionals $(29.4 \%)$; classes on food nutritional values and food processing $(18.7 \%)$; vegetable gardening classes $(8.2 \%)$; and experimental kitchens $(7.5 \%)$.

Healthy environment promotion was also reported in most PHCUs (77.7\%) regardless of their category and they included guidance for creating healthier environments $(80.6 \%)$, followed by interventions at local schools (49.5\%) and community centers (23.3\%).

Only $3.2 \%$ of PHCUs did not have any health promotion activity. Most PHCUs (62.3\%) reported having at least three programs in place and $8.4 \%$ offered all activities listed in our questionnaire.

Regarding regional differences, Table 3 shows the prevalence of health promotion programs by macroregion. Promotion of physical activity programs significantly varied amongst regions, being offered by an average of $39.8 \%$ of PHCUs, ranging from to $50.9 \%$ in the Southeast to $21.3 \%$ in the North. Promotion of healthy eating programs also showed significant regional variation, being reported in only $61.7 \%$ of PHCUs in the North and almost $80.0 \%$ in the Midwest. All other health promotion activities (tobacco and alcohol/drug cessation and healthy environment) were similarly prevalent in PHCUs of all regions.

\section{DISCUSSION}

Our study showed that health promotion programs are present in most PHCUs in Brazil. Almost all PHCUs $97.0 \%$ had at least one type of health promotion program in place and $60.0 \%$ offered three programs or

Table 1. Number of primary health care units selected, non-response and response rates by macroregion. Brazil, 2009.

\begin{tabular}{lccccc}
\hline Macroregion & Number of PHCUs selected & $\%$ & Non-response & $\%$ & Response rate $(\%)$ \\
\hline Midwest & 110 & 6.9 & 13 & 3.7 & 88.2 \\
Northeast & 629 & 39.3 & 174 & 49.9 & 72.3 \\
North & 138 & 8.6 & 58 & 16.6 & 58.0 \\
Southeast & 473 & 29.6 & 79 & 22.6 & 83.3 \\
South & 250 & 15.6 & 25 & 7.2 & 90.0 \\
Total & 1,600 & 100.0 & 349 & 100.0 & 78.2 \\
\hline
\end{tabular}

PHCU: Primary health care unit 
Table 2. Prevalence of health promotion programs by category of primary health care unit in the Unified Health System. Brazil, 2009.

\begin{tabular}{|c|c|c|c|c|c|}
\hline \multirow[b]{2}{*}{ Health promotion program } & \multicolumn{4}{|c|}{ Category of primary health care unit } & \\
\hline & FHS $(n=761)$ & TRAD $(n=295)$ & $\operatorname{MIX}(n=195)$ & $\begin{array}{c}\text { Total } \\
(\mathrm{N}=1,251)\end{array}$ & \\
\hline Physical activity & 39.8 & 37.4 & 43.3 & 39.8 & NS \\
\hline Tobacco cessation & 51.9 & 60.1 & 55.7 & 54.4 & $\mathrm{p}<0.05$ \\
\hline Healthy eating & 74.0 & 72.0 & 64.4 & 72.0 & $p<0.03$ \\
\hline Alcohol use cessation & 40.8 & 43.3 & 41.8 & 41.6 & NS \\
\hline Healthy environment & 79.4 & 74.4 & 75.8 & 77.7 & NS \\
\hline
\end{tabular}

FHS: Family Health Strategy only; TRAD: traditional care strategy; MIX: mixed combination of care strategies; NS: Non-significant

more. Considering that the national health promotion policy was adopted less than a decade ago, one can say these are encouraging results.

According to the World Health Organization (WHO), health promotion is a process of enabling people to increase control over health determinants and to improve their quality of life. In Brazil, this concept has been newly defined as "new health promotion", based on the idea that health promotion should aim to reduce health inequalities by ensuring opportunities to all people to have a leading role in the process of being healthy and improving their quality of life. ${ }^{13,14}$

The most prevalent health promotion programs in PHCUs in Brazil are promotion of healthy eating, healthy environment, and tobacco cessation. Smoking has a long history of prevention in Brazil given the widespread recognition of the harmful effects of tobacco use. ${ }^{15,16}$ Tobacco use prevention activities including visual campaigns, counseling and support groups are offered in more than half of the PHCU, but they are significantly more prevalent among the traditional PHCUs.

On the other hand, promotion of physical activity has a more recent history in Brazil. There are also a wider range of activities for promoting physical activity, and they require greater investments in skilled human resources, adequate spaces, referrals and appropriate equipment. ${ }^{4}$ Hence, we found in our study a relatively low prevalence of physical activity promotion programs (less than 40.0\%) in PHCUs. Nonetheless, many activities have been recently introduced in Brazil including the implementation and evaluation of programs like City Gyms and the nationwide program Health Academies. These types of programs provide fitness training classes in community settings and have shown great potential for increasing physical activity levels at the population level. ${ }^{9,18,21}$ It is encouraging that Brazil has the infrastructure in place to link up health care and community services to promote physical activity within its health system. These types of programs, also known as "exercise referral programs", have shown to be effective, at least in the short-term, and have helped adults in Europe, Australia, New Zealand and the Unites States lead a more physically active life. ${ }^{7}$ However, to our knowledge, Brazil is the only Latin American country that has developed a large-scale approach and implemented a national policy for promoting of physical activity within its health system.

Given the rapid aging process of the Brazilian population since the 1980 's $\mathrm{s}^{1,20}$ and an age-related risk of increasing physical inactivity, ${ }^{2,6}$ the prevalence of physical inactivity among adults is likely to increase. There is accumulating evidence linking healthy aging with active lifestyles, ${ }^{5, \mathrm{a}, \mathrm{j}}$ which should increase the demand for opportunities to participate in physical activities, especially within the health system.

Regional comparisons confirmed patterns of socioeconomic inequalities between the North/Northeast and South/Southeast as reflected in health indicators. For instance, in 2010 in Brazil, infant mortality rate was 15.3 per 1,000 live births nationwide while it was as high as 20.9 per 1,000 in the North and as low as 10.9 per 1,000 in the South. ${ }^{22}$ Health promotion programs tend to be more prevalent in the affluent South compared to more deprived regions such as the North. Physical activity promotion was the program that showed the greatest variation in prevalence, from $21.0 \%$ in the North to $51.0 \%$ in the Southeast. Special attention should be given to regional inequalities in access to health care, especially in the North and Northeast. Although designed to foster health promotion at the primary care level, the FHS did not seem to have significantly improved the availability of physical activity promotion in PHCUs. Nevertheless, our data did not allow to assessing the quality and effectiveness of these programs. Some studies have reported an impact of FHS in reducing hospital admission rates for ambulatory sensitive primary care conditions that are most related to chronic diseases..$^{12}$ Further studies are needed to investigate whether the quality of health promotion programs is different by category of PHCU.

i Pan American Health Organization. Physical activity for active aging. Geneva; 2002. Available from: http://bvse.bvsalud.org/dol/ docsonline/9/2/029-PAHO-ActAge-eng-all.pdf 
Table 3. Prevalence of the health promotion programs by macroregion of primary health care units in the Unified Health System. Brazil, 2009.

\begin{tabular}{lccccccc}
\hline \multirow{2}{*}{$\begin{array}{l}\text { Health promotion } \\
\text { program }\end{array}$} & $\begin{array}{l}\text { Southeast } \\
(\mathrm{n}=394)\end{array}$ & $\begin{array}{c}\text { Northeast } \\
(\mathrm{n}=455)\end{array}$ & $\begin{array}{c}\text { North } \\
(\mathrm{n}=80)\end{array}$ & $\begin{array}{c}\text { South } \\
(\mathrm{n}=225)\end{array}$ & $\begin{array}{c}\text { Midwest } \\
(\mathrm{n}=97)\end{array}$ & $\begin{array}{c}\text { Total } \\
(\mathrm{N}=1,251)\end{array}$ \\
\hline Physical activity & 50.9 & 34.7 & 21.3 & 34.7 & 45.9 & 39.8 & $\mathrm{p}<0.000$ \\
Tobacco cessation & 49.5 & 57.0 & 59.3 & 58.0 & 49.5 & 54.4 & $\mathrm{NS}$ \\
Healthy eating & 72.0 & 76.6 & 61.7 & 63.4 & 79.6 & 72.0 & $\mathrm{p}<0.001$ \\
Alcohol use cessation & 36.9 & 45.0 & 37.0 & 42.9 & 45.4 & 41.6 & $\mathrm{NS}$ \\
Healthy environment & 74.8 & 80.2 & 68.8 & 80.3 & 78.6 & 77.7 & $\mathrm{NS}$ \\
\hline
\end{tabular}

NS: Non-significant

Even though promotion of healthy diets was the most prevalent program in PHCUs, the 1999 National Nutrition Policy has not been fully implemented yet. ${ }^{10}$ This is a matter of concern due to growing obesity rates in Brazil. Although there are several guidelines to implement nutrition actions at the primary care level, our findings stress the importance of improving nutrition actions at PHCUs.

Less than half of PHCUs reported alcohol and illicit drug use prevention actions, and users were not usually referred to specialized care at a referral center. Primary care could effectively manage prevention and treatment actions including screening, brief interventions, and monitoring in individuals or populations at risk. ${ }^{23}$ Our data suggest that these approaches have to be urgently and rapidly disseminated among primary care providers.

As for healthy environment promotion at PHCUs, our data showed that it is very sensitive to intersectoral actions, which may be effective strategies to mitigate environmental hazards. For instance, a negative association between overweight prevalence and density of parks and public sport facilities has been reported in the city of Sao Paulo, Southeastern Brazil. ${ }^{11}$

The national health promotion policy has become a priority in the public health agenda in Brazil. Some health promotion programs like tobacco cessation are widely disseminated and have already reduced smoking prevalence among adults. ${ }^{16,17}$ Others like physical activity promotion are not yet available in most PHCUs but they are rapidly increasing across the country. Investments in infrastructure and staff training are vital for successful programs and our data show there is still a large gap within the public health system.

The study results provide valuable baseline input to assess future public health and health promotion actions as part of the national plan to control the rise of NCDs by 2022 . One of the plan's goals is to disseminate, implement and support programs like health academies, and other health promotion activities at the national level, embedded within Brazil's health care system.

\section{REFERENCES}

1. Carvalho JAM, Garcia RA. The aging process in the Brazilian population: a demographic approach. Cad Saude Publica. 2003;19(3):725-33. DOI:10.1590/S0102-311X2003000300005

2. Ferreira MT, Matsudo SM, Ribeiro MC, Ramos LR. Health-related factors correlate with behavior trends in physical activity level in old age: longitudinal results from a population in São Paulo, Brazil. BMC Public Health. 2010;10:690. DOI:10.1186/1471-2458-10-690

3. Florindo AA, Mielke GI, Gomes GA, Ramos LR, Bracco M, Parra DC, et al. Physical activity counseling in primary health care in Brazil: a national study on prevalence and associated factors. BMC Public Health. 2013;13:794. DOI:10.1186/1471-2458-13-794

4. Gomes GAO, Kokubun E, Mieke GI, Ramos L, Pratt M, Parra D, et al. Characteristics of Physical Activity Programs in Primary Health Care in Brazil. Cad Saude Publica. 2014; no prelo.

5. Grant BC. Should physical activity be on the healthy ageing agenda? Soc Policy J New Zealand. 2008;33:163-77.

6. Hallal PC, Andersen LB, Bull FC, Guthold R, Haskell W, Ekelund U, et al. Global physical activity levels: surveillance progress, pitfalls, and prospects. Lancet. 2012;380(9838):247-57. DOI:10.1016/S0140-6736(12)60646-1

7. Harrison RA, McNair F, Dugdill L. Access to exercise referral schemes - a population based analysis. J Public Health. 2005;27(4):326-30. DOI:10.1093/pubmed/fdi048

8. Hoehner CM, Soares J, Parra Perez D, Ribeiro IC, Joshu CE, Pratt M, et al. Physical activity interventions in Latin America: a systematic review. Am J Prev Med. 2008;34(3):224-33. DOI:10.1016/j.amepre.2007.11.016 
9. Hoehner CM, Ribeiro IC, Parra DC, Reis RS, Azevedo MR, Hino AA, et al. Physical activity interventions in Latin America: expanding and classifying the evidence. Am J Prev Med. 2013;44(3):e31-e40 DOI:10.1016/j.amepre.2012.10.026

10. Jaime PC, Silva ACF, Lima AMC, Bortolini GA. Ações de alimentação e nutrição na atenção básica: a experiência de organização no Governo Brasileiro. Rev Nutr. 2011;24(6):809-24. DOI:10.1590/S1415-52732011000600002

11. Jaime PC, Duran AC, Sarti FM, Lock K. Investigating environmental determinants of diet, physical activity, and overweight among adults in Sao Paulo, Brazil. J Urb Health. 2011;88(3):567-81. DOI:10.1007/s11524-010-9537-2

12. Macinko J, Oliveira VB, Turci MA, Guanais F, Bonolo PF, Lima-Costa MF. The influence of primary care and hospital supply on ambulatory care-sensitive hospitalizations among adults in Brazil, 1999 a 2007. Am J Public Health. 2011;101(10):1963-70. DOI:10.2105/AJPH.2010.198887

13. Malta DC, Castro AM, Gosh CS, Cruzll DKA, Bressanll A, Nogueira JD, et al. A Política Nacional de Promoção da Saúde e a agenda da atividade física no contexto do SUS. Epidemiol Serv Saude. 2009;18(1):79-86.

14. Malta DC, Morais Neto OL, Silva Jr JB. Apresentação do plano de ações estratégicas para o enfrentamento das doenças crônicas não transmissíveis no Brasil, 2011 a 2022. Epidemiol Serv Saude. 2011;20(4):425-38. DOI:10.5123/S1679-49742011000400002

15. Malta DC, Silva Jr JB. Policies to promote physical activity in Brazil. Lancet. 2012;380(9838):195-6. DOI:10.1016/S0140-6736(12)61041-1

16. Malta DC, Iser BPM, Sá NNB, Yokota RTC, Moura L, Claro RM, et al.Tendências temporais no consumo de tabaco nas capitais brasileiras, segundo dados do VIGITEL, 2006 a 2011. Cad Saude Publica. 2013;29(4):812-22. DOI:10.1590/S0102-311X2013000800018
17. Monteiro CA, Cavalcante TM, Moura EC, Claro RM, Szwarcwald CL. Population-based evidence of a strong decline in the prevalence of smokers in Brazil (1989-2003). Bull World Health Organ. 2007;85(7):527-34. DOI:10.2471/BLT.06.039073

18. Parra DC, McKenzie TL, Ribeiro IC, Ferreira Hino AA, Dreisinger M, Coniglio K, et al. Assessing physical activity in public parks in Brazil using systematic observation. Am J Public Health. 2010;100(8):1420-6. DOI:10.2105/AJPH.2009.181230

19. Pratt M, Brownson RC, Ramos LR, Malta DC, Hallal PC, Reis RS, et al. Project GUIA: a model for understanding and promoting physical activity in Brazil and Latin America. J Phys Act Health. 2010;7(Suppl 2):131-4.

20. Ramos LR, Veras RP, Kalache A. Envelhecimento populacional: uma realidade brasileira Rev Saude Publica. 1987;21(3):211-24. DOI:10.1590/S0034-89101987000300006

21. Simões EJ, Hallal $P$, Pratt $M$, Ramos $L R$, Munk $M$, Damascena W, et al. Effects of communitybased, professionally supervised intervention on physical activity levels among residents of Recife, Brazil. Am J Public Health. 2009;99(1):21-9. DOI:10.2105/AJPH.2008.141978

22. Victora CG, Aquino EM, Carmo Leal $M$, Monteiro CA, Barros FC, Szwarcwald CL. Maternal and child health in Brazil: progress and challenges. Lancet. 377(9780):1863-76. DOI:10.1016/S0140-6736(11)60138-4

23. Williams EC, Johnson ML, Lapham GT, Caldeiro RM, Chew L, Fletcher GS, et al. Strategies to implement alcohol screening and brief intervention in primary care settings: a structured literature review. Psychol Addict Behav. 2006;25(2):206-14. DOI:10.1037/a0022102

This study was supported by the Centers for Disease Control and Prevention's Prevention Research Centers Program contract U48/DP001903 (Applying Evidence-Physical Activity Recommendations in Brazil).

The findings and conclusions in this report are those of the authors and do not necessarily represent the official position of the Centers for Disease Control and Prevention.

Presented at the International Congress of Physical Activity and Public Health (ICPAPH), in Sydney, Australia, in 2012. The authors declare no conflict of interest. 


\section{HIGHLIGHTS}

The study investigated the presence or absence of five health promotion programs proposed by the National Health Promotion Policy in the primary care units of the Unified Health System (SUS) all over Brazil.

The absolute majority $(97.0 \%)$ of the units has one of these programs in operation and more than $60.0 \%$ have at least three programs. The prevalence of some programs differed significantly according to the region of Brazil, mainly to the detriment of the North region. The physical activity promotion program showed the lowest prevalence. It is the most recent program and it has received large investments from the Ministry of Health.

The results will help the Ministry of Health to assess the evolution of the National Health Promotion Policy and to identify regional deficiencies in the implementation of some programs.

Rita de Cássia Barradas Barata

Scientific Editor 